\title{
The Effectiveness of Using Games for Developing Young Learners' Grammar Competence
}

\begin{abstract}
The main aim of this paper is to explore the effectiveness of using games in teaching English grammar to young learners. Today there is an overall agreement among researchers in foreign language teaching and language acquisition that grammar should be taught at all levels of instruction, including to young learners, bearing in mind that it should be considered in the context of meaningful communication. The paper first presents a review of the literature in the area of grammar teaching and using games for language teaching purposes. The second part presents the results of an experimental study aimed at testing the hypothesis that activities based on grammar games are a more efficient strategy for teaching grammar than more traditional ELT activities. The results of the experiment prove the efficacy of using grammar games in teaching grammar to young learners.
\end{abstract}

Keywords: grammar teaching; young language learners; language learning games; communicative language teaching; form-focused instruction

\section{Učinkovitost rabe iger za razvijanje slovnične zmožnosti mlajših učencev}

\section{POVZETEK}

Prispevek preučuje učinkovitost rabe iger pri poučevanju angleščine na razredni stopnji osnovne šole. Dandanes se avtorji na področju poučevanja in usvajanja tujih jezikov v glavnem strinjajo, da je slovnico smiselno poučevati na vseh ravneh, vključno z zgodnjim učenjem tujega jezika, vendar ob tem opozarjajo, da mora biti slovnica vedno obravnavana v kontekstu smiselne komunikacije. $\mathrm{V}$ prispevku najprej predstavljamo pregled literature poučevanja slovnice na področju tujega jezika in rabe iger za namene poučevanja jezika. Nadalje predstavljamo rezultate eksperimentalne raziskave, katere namen je bil preveriti hipotezo, da so dejavnosti, ki temeljijo na slovničnih igrah, učinkovitejše za poučevanje slovnice kot bolj tradicionalne dejavnosti na področju poučevanja angleščine kot tujega jezika. Rezultati eksperimenta dokazujejo učinkovitost rabe slovničnih iger pri učenju slovnice na zgodnji stopnji.

Ključne besede: poučevanje slovnice; zgodnje učenje jezika; igre za učenje jezika; komunikacijsko poučevanje jezika; na obliko osredotočeno poučevanje 


\section{Introduction}

Teaching grammar has undoubtedly been one of the most controversial issues in the history of English language teaching, strongly influenced by different approaches which have dominated the area of foreign language teaching (FLT) in different periods. With the emergence of communicative language teaching (CLT) in the 1970s, grammar was first marginalised as the focus shifted from accuracy to fluency. Krashen's (1987) language acquisition theory rejected the explicit teaching of grammar on the grounds that language and grammar can be acquired subconsciously. However, the effectiveness of this theory was later questioned as reports of low writing proficiency and poor grammar came through. Two different ways of understanding the role of grammar developed in the process, the weak and the strong views (Nunan 2015). According to the strong view, learners will 'pick up' grammar subconsciously through communicative tasks, so there is no need to teach it explicitly. On the other hand, the weak view sees explicit grammar teaching as beneficial for language development. There is a general consensus among researchers today (Nunan 2015; Ellis 2006; Larsen-Freeman 2000; Cameron 2001) that there is a place for grammar in the foreign language curriculum, but that it should be considered in the context of meaningful communication and that learners need to be helped to link grammar items and structures with the communicative functions they perform in different contexts.

Most authors in the area of teaching English to young learners (YL) (Cameron 2001; Pinter 2006; Brewster, Ellis, and Girard 2002) agree that grammar is an essential component of language learning and should be taught at all levels, including YL. However, since young learners are able to comprehend meaningful messages, but are unable to analyse the language as a system, it is clear that grammar learning should be mostly implicit rather than explicit. In addition, given the learners' cognitive level, grammar should be presented and used within a meaningful context, reflecting authentic uses of language. As Cameron $(2001,122)$ notes, "a grammar-sensitive teacher will see the language patterns that occur in tasks, stories, songs, rhymes and classroom talk, and will have a range of techniques to bring these patterns to the children's notice, and to organise meaningful practice".

In the past, games were often seen as entertaining, relaxing activities by teachers, rather than as effective tools for achieving specific aims in the foreign language classroom. With the advent of communicative language teaching, however, it became clear that games provide much more than merely enjoyment and fun for language learners. In the communicative classroom, games give learners the opportunity to use and develop language in a creative and communicative manner by providing them with meaningful context. Besides being motivating and fun, games provide students with plenty of opportunities for practising pronunciation, vocabulary, grammar and the four language skills in an integrated way (Brewster, Ellis, and Girard 2002). The main aim of the present paper is thus to investigate the application of games in developing young learners' grammatical competence.

\section{Approaches to Teaching Grammar}

The poor grammatical competence of language learners, which was noted in the early development of CLT as well as later evaluations of different immersion programmes, 
resulted in several attempts to reintegrate grammar into foreign language teaching (Cameron 2001; Ellis 2006). A variety of grammar teaching models have emerged aimed at making learners aware of form/function mappings or connections between grammatical forms and the meanings which they typically signal (Batstone and Ellis 2009). The central question addressed by these attempts is to what extent it is sensible to direct the learners' attention to form whilst retaining the focus on the need to communicate (Sheen 2002). This is clearly illustrated in the debate revolving around the distinction made between 'focus on form' and 'focus on formS' proposed by Long (1998). The first type, 'focus on form', is related to situations in which the learners' attention is directed to particular language elements which emerge incidentally in a task in which there is an overt focus on meaning or communication (Sheen 2002; Doughty and Varela 1998). Grammar is taught in a series of separate lessons, usually involving a single grammatical structure (Ellis 2006). The theoretical framework for this option is related to the identity hypothesis according to which there are a number of parallels between first and second language acquisition, which both depend on comprehensible input deriving from natural communication. However, since there are important differences in the exposure to L2 and L1, it is necessary to direct the learners' attention to grammatical forms to compensate for these. On the other hand, the 'focus on formS' option reflects the discrete-point approach to teaching grammar according to which a language is best learnt by accumulating separate language features, such as verb endings or noun suffixes, but also functions, such as greetings or apologies (Doughty and Varela 1998). This view is based on the belief that the process of learning a foreign language is essentially the same as learning any other skill, as it derives from a person's general cognitive processes (Sheen 2002). As Ellis (2006) points out, there has been considerable debate over which of the two options is most effective in developing implicit knowledge.

Another problem is that the two terms are not used consistently in the ELT literature. While the differences between the two approaches might seem to be clear-cut at first sight, this is not the case (Sheen 2002, 304). One reason for confusion derives from the fact that the use of the terms 'form-focused instruction' or 'formal instruction' has led some authors to see the two terms as polar opposites, much like the difference between 'focus on form' and 'focus on communication' (Doughty and Varela 1998). As these two authors point out $(1998,4)$ ), "focus on form entails a focus on formal elements of language, whereas focus on formS is limited to such focus, and focus on meaning excludes it." On the other hand, several authors see focus on formS as useful and legitimate "provided that students are given chances to use the discrete forms they have studied in communication tasks" (Baleghizadeh and Mozaheb 2011, 365).

The controversy over which type of instruction is more effective is not so simple to resolve. In laying out a list of ten key assumptions about grammar teaching, Ellis $(2006,102)$ first argues that "an incidental focus-on-form approach is of special value because it affords an opportunity for extensive treatment of grammatical problems (in contrast to the intensive treatment afforded by a focus-on-formS approach)", but later also contends that "grammar instruction should take the form of separate grammar lessons (a focus-on-formS approach) and should also be integrated into communicative activities (a focus-on-form approach)". In a YL context, the focus on formS option used for communicative purposes may be especially useful, due to the learners' limited language competence. 
One type of instruction which entails focusing on form has been referred to as 'noticing', a concept introduced by Schmidt (1990). It refers to the process by which learners pick up the language they hear form different sources, known as 'input'. Input turns into 'intake' when learners pay conscious attention to specific features of the target language which are fed into the learning process. Noticing can be done in different ways, providing sufficient exposure and using a variety of noticing techniques to enhance the process of converting input into intake (Cross 2002; Richards and Burns 2012; Batstone 1996). In the YL classroom, noticing will necessarily take into account the cognitive level of learners, especially as regards the use of grammatical metalanguage.

It is important here to make two distinctions: first between explicit and implicit knowledge and then between explicit knowledge as analysed knowledge and as metalinguistic explanation (Ellis 2006). The former differentiates between knowledge which is learnt by paying conscious attention to form and that which is acquired subconsciously and accessed easily in the process of communication. The latter refers to the distinction between a conscious awareness of how a grammatical feature works, and a metalinguistic explanation which entails knowledge of grammatical metalanguage and the ability to understand explanations of rules. While it is clear that explicit metalinguistic explanation is not a productive grammar teaching strategy in the YL classroom, explicit focus on grammar in terms of analysed knowledge may be a valuable teaching technique. This is further discussed in the following chapter which focuses on different aspects of teaching grammar to young learners.

\section{Grammar and Young Learners}

There is a general agreement among authors in the field of teaching English to young learners (Cameron 2001; Brewster, Ellis, and Girard 2002; Pinter 2006) that it is possible to facilitate the natural acquisition of grammar through instruction. Pinter (2006) argues that it is natural for children to make grammatical mistakes in the early stages of language acquisition, not only in learning a foreign language, but also in acquiring the first language. In fact, some mistakes are universal and not the result of negative transfer from L1. The teacher therefore needs to attend to language form in different ways to help learners to internalise and automatize grammatical patterns so they can be retrieved efficiently in communication.

Cameron (2001, 105-6) illustrates the difference between explicit and implicit grammar teaching from the YL perspective through two opposing metaphors: the "building block" and the "organic" metaphor. The building block metaphor implies the introduction of grammar rules one-by-one as discrete blocks of knowledge, often using metalinguistic labels to describe the rule and following the sequence from 'easy' to 'difficult'. The building block sequence is clearly not appropriate for younger children whose ability to think about language in abstract, formal ways is still limited. The author proposes using a more organic metaphor with YLs for the growth of internal grammar, one that does not see grammar learning as "the piling up of discrete blocks of knowledge, but that captures the idea of non-linear and interconnected growth: grammar grows like a plant, perhaps, watered by meaningful language use, and pushing out new shoots while older stems are strengthened" $(2001,106)$. However, this does not mean that it is not useful or sensible to teach young language learners grammatical patterns explicitly as analysed language 
(cf. Ellis 2006 above). On the contrary, Cameron (2001) suggests occasionally applying explicit grammar instruction with children - as a "fertiliser at certain key points in the growing season". We would like to argue that this is a valuable metaphor in trying to calibrate and balance the introduction of different aspects of language in FL teaching.

Brewster, Ellis, and Girard (2002) further point out that by failing to attend to language form and, more generally, accuracy, learners will have difficulties participating in activities which focus on purposeful communication. As noted above, one way of supporting learners in this is to make them notice the grammatical patterns of the foreign language and help them make these patterns part of their internal grammar. Batstone (1994) suggests a useful sequencing of grammar learning activities which consists of three stages. The first one is "noticing" or "(re)noticing" and involves the learners becoming aware of the grammar patterns and connecting form and meaning. At the second stage, which is referred to as "(re)structuring", learners manipulate the forms and meaning through a series of controlled activities. In the last stage, or "proceduralising", learners use the language patterns by formulating their own meanings for communicative purposes. The three stages are especially valuable as they allow for a combination of both accuracy and fluency. A number of guided noticing activities may be used with young language learners, and some activities may be designed in such a way as to make the noticing more likely to occur, such as tasks which can only be completed by focusing on a particular grammar feature (Cameron 2001).

Kersten and Rohde (2013) caution that different grammar teaching strategies should not override the principle of meaningful communication and the role of a stimulating learning environment. A grammar lesson can be contextualised and made meaningful in various ways which the children can identify with. For example, stories and storytelling can be used as efficient meaningful context for teaching the use of articles (Puhner and Dagarin Fojkar 2018; Dagarin Fojkar, Skela, and Kovač 2013). The teacher can use audio or visual materials, realia and props, storytelling, problem solving, giving examples, showing grammar usage, playing games, etc. It is also important to consider that young learners are good observers. In order to make sense of what they hear or see, they make use of contextual clues, such as movement, intonation, gestures, actions and messages (Arikan 2009).

\section{Games as Language Teaching Tools}

Hadfield $(1998,4)$ defined a game as "an activity with rules, a goal, and an element of fun", and also made a distinction between linguistic and communicative games. The former are focused on linguistic accuracy and usually result in the production of a correct grammatical feature, while the latter are fluency-focused as they have a non-linguistic aim which may or may not involve language production. To exploit the full potential of games for language development, teachers need to be aware of what language learning or other educational gains they provide (Brewster, Ellis, and Girard 2002).

There are several reasons why games are considered an effective teaching tool in language teaching. One of the most salient advantages of using games is the fact that they provide a meaningful context in which the language is embedded. The most important characteristic of this context is that, at least as long as the game lasts, for its participants the game becomes 
an alternative and thus 'authentic' reality (Lewis and Bedson 1999). As such, it provides a platform for learner-learner interaction, the language used in the game is "a tool for the children to reach a goal which is not directly language related" (Lewis and Bedson 1999, 5). In addition, games are also effective language scaffolds as they commonly contain some kind of repetition, and since they are governed by rules they provide a frame which is to a certain extent predictable. The language of games is full of typical communicative patterns or chunks, such as 'my turn', 'give it to me' or 'I win' which are quickly learnt and enable the participant "easy access to social interaction on the playground" (Girard and Sionis 2004, 49).

Another advantage of using games in the classroom is that learners become active participants in the learning process. They are encouraged to play an active role and are thus given a chance to direct their own learning (Crookall and Oxford 1990 in Yolageldili and Arikan 2011), in a similar way as an active role in choosing their reading materials encourages learners to read more (Pirih 2015). This also affects the learners' motivation to learn a language. Students become naturally absorbed in trying to win the game and as a result they become more motivated and willing to learn (Deesri 2002; Yolageldili and Arikan 2011). In addition, the competitive or co-operative context encourages learners to pay attention and think intensively during the learning process, which enhances unconscious language acquisition (Chen 2005).

There are also several benefits which are more closely related to learning language patterns. First of all, games promote the memorisation of chunks of language, including useful pronunciation practice. In games, language patterns and chunks are usually "memorised through constant repetition in the form of 'hidden' or 'disguised' drills" (Brewster, Ellis, and Girard 2002, 175). Besides repetition, games also encourage more creative uses of language as learners negotiate, collaborate or compete in the informal context of the game (Brewster, Ellis, and Girard 2002).

Finally, learners are not exposed to the pressure of foreign language performance when playing a game. They thus become anxious to take an active part in the game and win rather than use the language correctly. Since learners are not afraid to be corrected or criticised for incorrect language use, they are more willing to use the language freely. Therefore, games play an important role in reducing foreign language anxiety and enhancing positive feelings towards foreign language learning (Chen 2005; Ibrahim 2017). In an action research aimed at exploring the effectiveness of learning vocabulary through games in the classroom, Huyen and Nga (2003) reported more efficient language learning and better retention of the learning material in a stress-free and comfortable environment.

\section{Study}

\subsection{Statement of Problem}

Copland, Garton and Burns (2014) identified grammar as one of the most important challenges in teaching English to young learners today, in addition to teaching speaking, motivation, differentiating learning, teaching large classes, discipline, and teaching writing. The overall objective of the present paper is, therefore, to explore different ways of enhancing the effectiveness of grammar teaching in the young learners classroom by analysing the application of games in developing young learners' grammatical competence. 
Despite the overall consensus among researchers and teaching practitioners that games are useful teaching tools in learning English grammar in EFL classes, there are few studies which reveal the actual effects of games on developing grammatical competence. In addition, in a small-scale study aimed at identifying teachers' attitudes towards using games in teaching an FL, Yolageldili and Arikan (2011) concluded that while teachers see the pedagogical value of using games in their YL classrooms, they do not use them as frequently as we might expect.

The main aim of the present study is to promote the use of games for developing grammatical competence in the $\mathrm{YL}$ classroom by investigating the effectiveness of using grammar games with young learners aged 10/11. To this end, an experiment was carried out in two primary schools in Slovenia.

\subsection{Participants}

As can be seen from Table 1, the sample $(\mathrm{n}=85)$ consisted of four groups of fifth graders (two experimental and two control groups) from two primary schools in Slovenia, an experimental and a control group at each school. All the students had the same amount of exposure to English language courses at school; it was their second year of formal English language learning.

TABLE 1. Sample of participants.

\begin{tabular}{|l|c|c|}
\hline & Experimental group & Control group \\
\hline School 1 & 21 & 19 \\
\hline School 2 & 23 & 22 \\
\hline Total & 44 & 41 \\
\hline
\end{tabular}

\subsection{Procedure}

At the beginning of the experiment, the participants were pre-tested using an adapted version of The English Unlimited Placement Test (Cambridge University Press 2010) to determine the differences in English language proficiency between the experimental and control groups. A week after the placement test was administered, a lesson was carried out in the four groups aimed at developing grammatical competence with a focus on the use of present continuous for actions in progress at the moment of speaking. The learners in the control group received instruction which was mostly teacher-centred, the teacher modelled the language using gestures and body language, examples of language use were presented on the whiteboard with pictures and PP slides, with learners copying the sentences into their notebooks. Controlled practice was based on teacher-class interaction and question-answer drills, followed by an activity in which the learners described a picture using the present continuous. At the end of the lesson, the participants completed a worksheet with the language point being practiced.

The experimental group received instruction which was mostly learner-centred and contained activities based on grammar games, which was the main aspect tested in the experiment. The lesson started with a miming activity in which learners had to guess what their school friends were doing. The second activity was based on a strategy board game similar to the board game snakes and ladders. In this game, learners in groups of four rolled the die and moved across the board. When they landed on a square with an animal, they had to answer the question 
put forward by the player next in line about what the animal was doing. The third activity was a card game for pairs in which learners had to match the animals with respective actions, and the last activity was a memory game which required learners to match pictures with the descriptions of the actions shown in them.

Following the lessons, the learners were administered a post-test which consisted of 15 items at the starter and elementary levels. Eight of the items referred to the correct use of the present continuous.

\subsection{Results}

The quantitative data were analysed using the SPSS software package and values were recorded as means $(\mathrm{M})$ and standard deviations (SD). An independent-samples t-test was carried out to compare the test scores for the experimental and control groups. Homogeneity of variance was assumed using the non-parametric Levene's test. The standard of sig. $<0.05$ was used in order to depict the statistical significance throughout the study.

Learners were first administered a pre-test which contained 15 items on two levels - starter and elementary. The results of the t-test showed that the differences in the average amount of points gained by the experimental and control groups for individual items in the test were not statistically significant (sig.>0.05). In fact, the two groups gained exactly the same amount of points in several items. In addition, we calculated the coefficient of difficulty for each item in the test so that the pre-test and post-test results could be compared. After the intervention in the form of lessons, a post-test was administered. The number of items and scoring procedure of the post-test were the same as the pre-test. As can be seen from Table 2, the items were divided into two levels of difficulty, which differed in the number of points given.

TABLE 2. Items according to the level of difficulty.

\begin{tabular}{|l|l|l|}
\hline Level & Items & No. of points \\
\hline Starter level & $1,2,3,4,5,6,7,8,11,141$ & 1 \\
\hline Elementary level & $9,10,12,13,152$ & 2 \\
\hline
\end{tabular}

Table 3 provides descriptive statistics for the experimental group 1 (ExG1) and control group 1 (CoG1) for items in the placement test which test the correct use of the present continuous (Items 5, 5, 8, 10, 12, 13, 14 and 15). The values presented are the number of learners in the group $(\mathrm{N})$, the coefficient of difficulty for each item (Item Diff.), the mean value of the number of points gained $(\mathrm{M})$, standard deviation $(\mathrm{SD})$, and finally the Levene's test and t-test results.

TABLE 3. Post-test results of the present continuous items (ExG1 and CoG1).

\begin{tabular}{|c|c|c|c|c|c|c|c|c|c|c|}
\hline \multirow{2}{*}{ Item } & \multirow{2}{*}{ Groups } & \multirow{2}{*}{$\mathrm{N}$} & \multirow{2}{*}{$\begin{array}{l}\text { Item } \\
\text { Diff. }\end{array}$} & \multirow{2}{*}{ M } & \multirow{2}{*}{ SD } & \multicolumn{2}{|c|}{ Levene's test } & \multicolumn{3}{|c|}{ T-test } \\
\hline & & & & & & $\mathrm{F}$ & $P$ & $t$ & $\mathrm{df}$ & sig. \\
\hline \multirow{2}{*}{5} & CoG1 & 19 & 0.526 & 0.53 & 0.513 & \multirow{2}{*}{79.561} & \multirow{2}{*}{0.000} & \multirow{2}{*}{-3.356} & \multirow{2}{*}{23.802} & \multirow{2}{*}{0.003} \\
\hline & ExG1 & 21 & 0.952 & 0.95 & 0.218 & & & & & \\
\hline
\end{tabular}




\begin{tabular}{|c|c|c|c|c|c|c|c|c|c|c|}
\hline \multirow{2}{*}{ Item } & \multirow{2}{*}{ Groups } & \multirow{2}{*}{$\mathrm{N}$} & \multirow{2}{*}{$\begin{array}{l}\text { Item } \\
\text { Diff. }\end{array}$} & \multirow{2}{*}{ M } & \multirow{2}{*}{ SD } & \multicolumn{2}{|c|}{ Levene's test } & \multicolumn{3}{|c|}{ T-test } \\
\hline & & & & & & $\mathrm{F}$ & $P$ & $\mathrm{t}$ & $\mathrm{df}$ & sig. \\
\hline \multirow{2}{*}{6} & CoG1 & 19 & 0.579 & 0.58 & 0.507 & \multirow{2}{*}{8.969} & \multirow{2}{*}{0.005} & \multirow{2}{*}{-1.582} & \multirow{2}{*}{34.318} & \multirow{2}{*}{0.123} \\
\hline & ExG1 & 21 & 0.809 & 0.81 & 0.402 & & & & & \\
\hline \multirow{2}{*}{8} & CoG1 & 19 & 0.789 & 0.79 & 0.419 & \multirow{2}{*}{4.328} & \multirow{2}{*}{0.044} & \multirow{2}{*}{-0.991} & \multirow{2}{*}{32.373} & \multirow{2}{*}{0.329} \\
\hline & ExG1 & 21 & 0.905 & 0.90 & 0.301 & & & & & \\
\hline \multirow{2}{*}{10} & CoG1 & 19 & 0.421 & 0.84 & 1.015 & \multirow{2}{*}{8.969} & \multirow{2}{*}{0.005} & \multirow{2}{*}{-2.665} & \multirow{2}{*}{34.318} & \multirow{2}{*}{0.012} \\
\hline & ExG1 & 21 & 0.809 & 1.62 & 0.805 & & & & & \\
\hline \multirow{2}{*}{12} & CoG1 & 19 & 0.684 & 1.37 & 0.955 & \multirow{2}{*}{14.678} & \multirow{2}{*}{0.000} & \multirow{2}{*}{-1.727} & \multirow{2}{*}{29.787} & \multirow{2}{*}{0.095} \\
\hline & ExG1 & 21 & 0.905 & 1.81 & 0.602 & & & & & \\
\hline \multirow{2}{*}{13} & CoG1 & 19 & 0.368 & 0.74 & 0.991 & \multirow{2}{*}{6.038} & \multirow{2}{*}{0.019} & \multirow{2}{*}{-3.071} & & \\
\hline & ExG1 & 21 & 0.809 & 1.62 & 0.805 & & & & | & 0.004 \\
\hline & CoG1 & 19 & 0.316 & 0.32 & 0.478 & & 001 & (20) & o & ( \\
\hline 14 & ExG1 & 21 & 0.857 & 0.86 & 0.359 & 1.109 & 0.011 & -4.021 & 33.258 & 0.000 \\
\hline & CoG1 & 19 & 0.368 & 0.74 & 0.991 & & & & 20 & 001 \\
\hline 15 & ExG1 & 21 & 0.762 & 1.52 & 0.873 & 2.970 & 0.094 & $-2.0 / 0$ & 58 & 0.011 \\
\hline
\end{tabular}

As we can see from Table 3, the first experimental group scored significantly higher than the first control group in all items which required the participants to choose the correct use of the present continuous. The greatest differences between the two groups can be noted in items 5 , $10,13,14$ and 15, where the differences are also statistically significant (sig.<0.05). These results are also reflected in the item difficulty (Item Diff.), which shows the proportion of students (p value) who answered an item correctly. In this case, larger $\mathrm{p}$ values indicate that the students found the items easier, while smaller $p$ values mean the items were more difficult for them. As can be seen from Table 3, the participants in the experimental group found the items in the test less difficult than the learners in the control group as the coefficient of difficulty is higher in each item of the experimental group, with the greatest differences in items 5, 10, 14 and 15.

TABLE 4. Post-test results of other items (ExG1 and CoG1).

\begin{tabular}{|c|c|c|c|c|c|c|c|c|c|c|}
\hline \multirow{2}{*}{ Item } & \multirow{2}{*}{ Group } & \multirow{2}{*}{$\mathrm{N}$} & \multirow{2}{*}{$\begin{array}{l}\text { Item } \\
\text { Diff. }\end{array}$} & \multirow{2}{*}{$\mathbf{M}$} & \multirow{2}{*}{ SD } & \multicolumn{2}{|c|}{ Levene's test } & \multicolumn{3}{|c|}{ t-test } \\
\hline & & & & & & $\mathrm{F}$ & $\mathbf{P}$ & $\mathrm{t}$ & $\mathrm{df}$ & sig. \\
\hline \multirow[b]{2}{*}{1} & COG1 & 19 & 0.421 & 0.42 & 0.507 & \multirow{2}{*}{8.969} & \multirow{2}{*}{0.005} & \multirow{2}{*}{-2.665} & \multirow{2}{*}{34.318} & \multirow{2}{*}{0.012} \\
\hline & EXG1 & 21 & 0.809 & 0.81 & 0.402 & & & & & \\
\hline \multirow{2}{*}{2} & COG1 & 19 & 0.947 & 0.95 & 0.229 & \multirow{2}{*}{4.970} & \multirow{2}{*}{0.032} & \multirow{2}{*}{-1.000} & \multirow{2}{*}{18.000} & \multirow{2}{*}{0.331} \\
\hline & EXG1 & 21 & 1.000 & 1.00 & 0.000 & & & & & \\
\hline \multirow{2}{*}{3} & COG1 & 19 & 0.947 & 0.95 & 0.229 & \multirow{2}{*}{4.970} & \multirow{2}{*}{0.032} & \multirow{2}{*}{-1.000} & \multirow{2}{*}{18.000} & \multirow{2}{*}{0.331} \\
\hline & EXG1 & 21 & 1.000 & 1.00 & 0.000 & & & & & \\
\hline
\end{tabular}




\begin{tabular}{|c|c|c|c|c|c|c|c|c|c|c|}
\hline \multirow{2}{*}{ Item } & \multirow{2}{*}{ Group } & \multirow{2}{*}{$\mathrm{N}$} & \multirow{2}{*}{$\begin{array}{l}\text { Item } \\
\text { Diff. }\end{array}$} & \multirow{2}{*}{ M } & \multirow{2}{*}{ SD } & \multicolumn{2}{|c|}{ Levene's test } & \multicolumn{3}{|c|}{ t-test } \\
\hline & & & & & & $\mathrm{F}$ & $P$ & $t$ & df & sig. \\
\hline \multirow{2}{*}{4} & COG1 & 19 & 0.947 & 0.95 & 0.229 & \multirow{2}{*}{1.028} & \multirow{2}{*}{0.317} & \multirow{2}{*}{0.500} & \multirow{2}{*}{38} & \multirow{2}{*}{0.620} \\
\hline & EXG1 & 21 & 0.905 & 0.90 & 0.301 & & & & & \\
\hline \multirow{2}{*}{7} & COG1 & 19 & 0.526 & 0.37 & 0.496 & \multirow{2}{*}{0.025} & \multirow{2}{*}{0.874} & \multirow{2}{*}{-1.594} & \multirow{2}{*}{38} & \multirow{2}{*}{0.119} \\
\hline & EXG1 & 21 & 0.667 & 0.62 & 0.498 & & & & & \\
\hline \multirow{2}{*}{9} & COG1 & 19 & 0.579 & 1.16 & 1.015 & \multirow{2}{*}{5.080} & \multirow{2}{*}{0.030} & \multirow{2}{*}{-1.217} & \multirow{2}{*}{35.752} & \multirow{2}{*}{0.232} \\
\hline & EXG1 & 21 & 0.762 & 1.52 & 0.873 & & & & & \\
\hline \multirow{2}{*}{11} & COG1 & 19 & 0.684 & 0.68 & 0.478 & \multirow{2}{*}{0.162} & \multirow{2}{*}{0.690} & \multirow{2}{*}{-0.202} & \multirow{2}{*}{38} & \multirow{2}{*}{0.841} \\
\hline & $\overline{\text { EXG1 }}$ & 21 & 0.714 & 0.71 & 0.463 & & & & & \\
\hline
\end{tabular}

Table 4 presents the results of the post-test for items other than the ones testing the present continuous form. As we can see, the differences between the experimental and control groups are considerably smaller compared to those in Table 3 . While the experimental group performed better than the control group in the majority of items (the exception is item 4, where the control group scored 0.95 points and the experimental 0.90 points on average), in general there is a very small difference between the two groups, and a statistical difference between the two groups was identified only for item 1 . This is also reflected in the smaller differences between the two groups in the level of difficulty of the items, which are less pronounced than the differences related to the items in Table 3.

TABLE 5. Post-test results of the present continuous items (ExG2 and CoG2).

\begin{tabular}{|c|c|c|c|c|c|c|c|c|c|c|}
\hline \multirow{2}{*}{ Item } & \multirow{2}{*}{ Group } & \multirow[b]{2}{*}{$\mathrm{N}$} & \multirow{2}{*}{$\begin{array}{l}\text { Item } \\
\text { Diff. }\end{array}$} & \multirow{2}{*}{ M } & \multirow{2}{*}{ SD } & \multicolumn{2}{|c|}{ Levene's test } & \multicolumn{3}{|c|}{ t-test } \\
\hline & & & & & & $\mathrm{F}$ & P & $\mathrm{t}$ & $\mathrm{df}$ & sig. \\
\hline \multirow{2}{*}{5} & $\overline{\mathrm{COG} 2}$ & 22 & 0.636 & 0.64 & 0.492 & \multirow{2}{*}{14.925} & \multirow{2}{*}{0.000} & \multirow{2}{*}{-1.834} & \multirow{2}{*}{37.427} & \multirow{2}{*}{0.075} \\
\hline & EXG2 & 23 & 0.869 & 0.87 & 0.344 & & & & & \\
\hline \multirow{2}{*}{6} & COG2 & 22 & 0.409 & 0.41 & 0.503 & \multirow{2}{*}{19.890} & \multirow{2}{*}{0.000} & \multirow{2}{*}{-3.567} & \multirow{2}{*}{36.948} & \multirow{2}{*}{0.001} \\
\hline & EXG2 & 23 & 0.869 & 0.87 & 0.344 & & & & & \\
\hline \multirow{2}{*}{8} & COG2 & 22 & 0.818 & 0.82 & 0.395 & \multirow[b]{2}{*}{10.465} & \multirow{2}{*}{0.002} & \multirow{2}{*}{-1.460} & \multirow{2}{*}{31.558} & \multirow{2}{*}{0.154} \\
\hline & EXG2 & 23 & 0.956 & 0.96 & 0.209 & & & & & \\
\hline \multirow{2}{*}{10} & COG2 & 22 & 0.318 & 0.64 & 0.953 & \multirow{2}{*}{5.099} & \multirow{2}{*}{0.029} & \multirow{2}{*}{-3.911} & \multirow{2}{*}{40.495} & \multirow{2}{*}{0.000} \\
\hline & EXG2 & 23 & 0.826 & 1.65 & 0.775 & & & & & \\
\hline 12 & $\begin{array}{l}\text { COG2 } \\
\text { FYC }\end{array}$ & $\frac{22}{23}$ & $\frac{0.727}{0.012}$ & 1.45 & $\frac{0.912}{0.576}$ & 12.742 & 0.001 & -1.626 & 35.207 & 0.113 \\
\hline & $\frac{\mathrm{LAU} L}{\mathrm{COG} 2}$ & $\frac{23}{22}$ & $\frac{0.913}{0.500}$ & $\frac{1.0 J}{1.00}$ & $\frac{0.5 / 0}{1.024}$ & & & & & \\
\hline 13 & EXG2 & 23 & 0.869 & 1.74 & 0.689 & 25.314 & 0.001 & -2.829 & 36.579 & 0.008 \\
\hline 14 & COG2 & 22 & 0.591 & 0.59 & 0.503 & 35845 & 0000 & -2620 & 33124 & 0013 \\
\hline 14 & EXG2 & 23 & 0.913 & 0.91 & 0.288 & 35.845 & 0.000 & & & \\
\hline 15 & $\overline{\mathrm{COG} 2}$ & 22 & 0.409 & 0.82 & 1.006 & 19.890 & 0.000 & -3.567 & 36.948 & 0.001 \\
\hline 15 & EXG2 & 23 & 0.869 & 1.65 & 0.689 & 19.890 & 0.000 & $-3.50 /$ & 30.948 & 0.001 \\
\hline
\end{tabular}

As can be seen from Table 5, similar to the results of the first experimental and control groups, the second experimental group also scored considerably higher than the second control group in all items which tested the correct use of the present continuous. The greatest differences 
between the two groups can be noted in items $6,10,13,14$ and 15, where the differences are also statistically significant (sig. $<0.05)$. Table 5 shows that participants in the experimental group found the items in the test less difficult than the learners in the control group, as the coefficient of difficulty (Item Diff.) is higher in each item of the experimental group, with the greatest differences in items 13 and 15.

TABLE 6. Post-test results of other items (ExG2 and CoG2).

\begin{tabular}{|c|c|c|c|c|c|c|c|c|c|c|}
\hline \multirow{2}{*}{ Item } & \multirow{2}{*}{ Group } & \multirow{2}{*}{$\mathrm{N}$} & \multirow{2}{*}{$\begin{array}{l}\text { Item } \\
\text { Diff. }\end{array}$} & \multirow{2}{*}{ M } & \multirow{2}{*}{ SD } & \multicolumn{2}{|c|}{ Levene's test } & \multicolumn{3}{|c|}{ t-test } \\
\hline & & & & & & $\mathrm{F}$ & $\mathrm{P}$ & $\mathrm{t}$ & df & sig. \\
\hline \multirow{2}{*}{1} & COG2 & 22 & 0.818 & 0.82 & 0.395 & \multirow{2}{*}{1.604} & \multirow{2}{*}{0.212} & \multirow{2}{*}{0.626} & \multirow{2}{*}{43} & \multirow{2}{*}{0.535} \\
\hline & EXG2 & 23 & 0.739 & 0.74 & 0.449 & & & & & \\
\hline \multirow{2}{*}{2} & COG2 & 22 & 0.864 & 0.86 & 0.351 & \multirow{2}{*}{0.013} & \multirow{2}{*}{0.910} & \multirow{2}{*}{-0.057} & \multirow{2}{*}{43} & \multirow{2}{*}{0.955} \\
\hline & EXG2 & 23 & 0.869 & 0.87 & 0.344 & & & & & \\
\hline \multirow{2}{*}{3} & COG2 & 22 & 0.591 & 0.59 & 0.503 & \multirow{2}{*}{11.763} & \multirow{2}{*}{0.001} & \multirow{2}{*}{-1.751} & \multirow{2}{*}{39.462} & \multirow{2}{*}{0.088} \\
\hline & EXG2 & 23 & 0.826 & 0.83 & 0.388 & & & & & \\
\hline \multirow{2}{*}{4} & COG2 & 22 & 0.818 & 0.82 & 0.395 & \multirow{2}{*}{3.619} & \multirow{2}{*}{0.064} & \multirow{2}{*}{-0.924} & \multirow{2}{*}{43} & \multirow{2}{*}{0.361} \\
\hline & EXG2 & 23 & 0.913 & 0.91 & 0.288 & & & & & \\
\hline \multirow{2}{*}{7} & COG2 & 22 & 0.545 & 0.55 & 0.510 & \multirow{2}{*}{0.066} & \multirow{2}{*}{0.799} & \multirow{2}{*}{-0.130} & 43 & 0.897 \\
\hline & EXG2 & 23 & 0.565 & 0.57 & 0.507 & & & & & \\
\hline & COG2 & 22 & 0.818 & 1.64 & 0.790 & $02 / 2$ & & & & \\
\hline 9 & EXG2 & 23 & 0.783 & 1.57 & 0.843 & 0.343 & 0.701 & 0.292 & 43 & $0.1 / 2$ \\
\hline 11 & COG2 & 22 & 0.682 & 0.73 & 0.456 & 5552 & 0073 & 1727 & רח8 & 0001 \\
\hline 11 & EXG2 & 23 & 0.478 & 0.48 & 0.511 & 3.352 & 0.025 & $1 . / 27$ & 42.002 & 0.091 \\
\hline
\end{tabular}

Table 6 presents the results of the post-test in items other than the ones testing the present continuous form. As we can see, the differences between the experimental and control groups are considerably smaller compared to those in Table 5 . The experimental group performed better than the control group on items 1 (mean score 0.82 compared to 0.74 ), 9 (1.64 compared to 1.57 ) and 11 (0.73 compared to 0.48 ), which is also reflected in the item level of difficulty. The coefficient of difficulty of these items is higher for the control group, which means that the participants found these items in the test easier. The score differences between the two groups are marginal for items 2, 4 and 7, and none of them is statistically significant (sig. > 0.05).

\section{Discussion and Conclusion}

This empirical study was aimed at exploring the effectiveness of using grammar games for developing grammar competence in a young learners' classroom. The results of the experiment presented above indicate that the use of grammar games is indeed an efficient teaching strategy for language development. Both experimental groups performed better than the control groups in all the items which contained the grammatical feature tested, and the differences were statistically significant for the majority of items. These results indicate that there are clear benefits in using games for language teaching purposes. This is in line with the conclusions drawn from the literature review which emphasise that games are not 
only time-fillers, motivating and fun, but can also be used for effective language practice, as argued by Brewster, Ellis, and Girard (2002). Games are learner-centred, create a meaningful context for language use, promote communicative competence and the learning of language skills in an integrated way. Furthermore, they enhance the learners' participatory attitudes and reduce language learning anxiety, thus motivating even shy learners to take part and use the language. Finally, games cater to young learners' needs and help teachers contextualize language instruction.

What are the implications of the results of this study for teaching grammar to young learners? As noted above, few issues have provoked more passionate and heated debates in foreign language teaching than grammar. There is a general consensus among researchers today that while grammar should be taught as a component of communicative competence, there are also clear benefits in using a more direct focus on language forms. This can be done in a variety of ways, considering the learners' needs and preferences. Today, the question is no longer whether grammar should or should not be taught, but rather how to teach it considering the learners' age, level and needs. As argued by Lewis and Bedson (1999), the use of games gives young learners plenty of opportunities for internalising grammatical patterns and vocabulary in a way which is natural and meaningful for them.

\section{References}

Arikan, Arda. 2009. "Environmental Peace Education in Foreign Language Learners' English Grammar Lessons." Journal of Peace Education 6 (1): 87- 99. https://doi.org/10.1080/17400200802655064.

Baleghizadeh, Sasan, and Mohammad Amin Mozaheb. 2011. "A Profile of an Effective EFL Grammar Teacher." Journal of Language Teaching \& Research 2 (2): 364-69. https://doi.org/10.4304/jltr.2.2.364 -369 .

Batstone, Rob. 1994. Grammar. Oxford: Oxford University Press.

—. 1996. "Key Concepts in ELT: Noticing." ELT Journal 50 (3): 273. https://doi.org/10.1093/elt/50 .3.273.

Batstone, Rob, and Rod Ellis. 2009. "Principled Grammar Teaching." System 37 (2): 194-204. https://doi .org/10.1016/j.system.2008.09.006.

Brewster, Jean, Gail Ellis, and Denis Girard. 2002. The Primary English Teachers' Guide. Harlow: Penguin.

Cameron, Lynne. 2001. Teaching Languages to Children. Cambridge: Cambridge University.

Chen, Jung I. 2005. "Using Games to Promote Communicative Skills in Language Learning." The Internet TESL Journal 11 (2): 1-4.

Copland, Fiona, Sue Garton, and Anne Burns. 2014. "Challenges in Teaching English to Young Learners: Global Perspectives and Local Realities.” TESOL Quarterly 48 (4): 738-62. https://doi.org/10.1002 /tesq.148.

Crookall, David, and Rebecca Oxford, eds. 1990. Simulation, Gaming, and Language Learning. New York: Newbury House.

Cross, Jeremy. 2002. "Noticing in SLA: Is it a Valid Concept?” TESL-EJ 6 (3). http://www.tesl-ej.org/ej23 la2.html

Dagarin Fojkar, Mateja, Janez Skela, and Polonca Kovac. 2013. "A Study of the Use of Narratives in Teaching English as a Foreign Language to Young Learners." English Language Teaching 6 (6): 21-28. https://doi.org/21-28. 10.5539/elt.v6n6p21.

Deesri, Angkana. 2002. "Games in the ESL and EFL Class." The Internet TESL Journal 8 (9): 1-5.

Doughty, Catherine, and Elisabeth Varela. 1998. "Communicative Focus on Form." In Focus on Form in Classroom Second Language Acquisition, edited by Catherine Doughty and Jessica Williams, 114-38. New York: Cambridge University Press. 
Ellis, Rod. 2006. "Current Issues in the Teaching of Grammar: An SLA Perspective.” TESOL Quarterly 40 (1): 83-107. https://doi.org/10.2307/40264512.

Girard, Marie, and Sionis Claude. 2004. "The Functions of Formulaic Speech in the L2 Class." Pragmatics 14 (1): 31-53. https://doi.org/10.1075/prag.14.1.01gir.

Hadfield, Jill. 1998. Elementary Vocabulary Games. Harlow: Pearson Education Limited.

Huyen, Nguyen Thi Thanh, and Khuat Thi Thu Nga. 2003. "Learning Vocabulary Through Games." Asian EFL Journal 5 (4): 90-105.

Ibrahim, Abdelrazig. 2017. "Advantages of Using Language Games in Teaching English as a Foreign Language in Sudan Basic Schools." American Scientific Research Journal for Engineering, Technology, and Sciences 37 (1): 140-50.

Kersten, Kristin, and Andreas Rohde. 2013. "Teaching English to Young Learners. Language Acquisition and Use in Multilingual Contexts." In Language Acquisition and Use in Multilingual Contexts, edited by Anna Flyman Mattsson and Catrin Norrby, 107-22. Lund: Lund University.

Krashen, Stephen. 1987. Principles and Practices in Second Language Acquisition. New York: Prentice-Hall.

Larsen-Freeman, Diane. 2000. Techniques and Principles in Language Teaching. Oxford: Oxford University Press.

Lewis, Gordon, and Gunther Bedson.1999. Games for Children. Oxford: Oxford University Press.

Long, Michael H. 1998. "Focus on Form Theory, Research, and Practice." In Focus on Form in Classroom Second Language Acquisition, edited by Michael H. Long and Peter Robinson, 15-41. Cambridge: Cambridge University Press.

Nunan, David. 2015. Teaching English to Speakers of Other Languages: An Introduction. New York: Routledge.

Pinter, Annamaria. 2006. Teaching Young Language Learners. Oxford: Oxford University Press.

Pirih, Anja. 2015. "Who Says They Don't Read? Slovene Elementary School Students' Reading Motivation in EFL." Journal of Elementary Education 8 (1-2): 113-32.

Puhner, Nataša, and Mateja Dagarin Fojkar. 2018. "Developing EFL Writing with Year 5 Pupils by Writing Summaries." ELOPE: English Language Overseas Perspectives and Enquiries 15 (2): 97-113. https://doi.org/10.4312/elope.15.2.97-113.

Richards, Jack. C., and Anne Burns, eds. 2012. The Cambridge Guide to Pedagogy and Practice in Second Language Teaching. Cambridge: Cambridge University Press.

Schmidt, Richard W. 1990. "The Role of Consciousness in Second Language Learning." Applied Linguistics 11 (2): 129-58. https://doi.org/10.1093/applin/11.2.129.

Sheen, Ron. 2002. “'Focus on Form' and 'Focus on Forms.”' ELT Journal 56 (3): 303-5. https://doi.org/10 $.1093 /$ elt/56.3.303.

Yolageldili, Gulin, and Arda Arikan. 2011. "Effectiveness of Using Games in Teaching Grammar to Young Learners.” Elementary Education Online 10 (1): 219-29. 